\title{
Beyond History: The List of The Most Well Studied Human Protein Structures
}

\author{
Zhen-lu Li ${ }^{1 *}$ and Matthias Buck ${ }^{1,2^{*}}$ \\ ${ }^{I}$ Department of Physiology and Biophysics, Case Western Reserve University, School of Medicine, 10900 Euclid Avenue, \\ Cleveland, Ohio 44106, U. S. A. ${ }^{2}$ Department of Pharmacology; Department of Neurosciences and Case Comprehensive \\ Cancer Center, Case Western Reserve University, School of Medicine, 10900 Euclid Avenue, Cleveland, Ohio 44106, U. S. A.
}

- Corresponding authors: Z.Li (zhenlu.li@,case.edu) and M.Buck(matthias.buck@,case.edu)

- ORCHID IDs: Z. Li: 0000-0003-2101-8237～M. Buck: 0000-0002-2958-0403

Of 20,000 or so canonical human protein sequences, as of July 2020,6,747 proteins have had their full or partial medium to high resolution structures determined by x-ray crystallography or other methods. Which of these proteins dominate the protein database (the PDB) and why? In this paper, we list the 272 top protein structures based on the number of their PDB depositions. This set of proteins accounts for more than $40 \%$ of all available human PDB entries and represent past trend and current status for protein science. We briefly discuss the relationship which some of the prominent protein structures have with protein biophysics research and mention their relevance to human diseases. The information may inspire researchers who are new to protein science, but it also provides a year 2020 snap-shot for the state of protein science.

\section{Main Text}

The number of human protein-coding genes is estimated to be around 20,000, which would result in the same number of full length, non-modified proteins. ${ }^{1}$ However, the real number of proteins in the human proteome increases dramatically as a consequence of alternative splicing, single amino acid polymorphisms between chromosomes and especially due to posttranslational modifications. ${ }^{2}$ By July 2020, there are 20,367 reviewed entries of full length human proteins in the Uniprot database, which is easily accessed via a webserver (http://uniprot.org/). The analysis, based on the 20,367 proteins, indicates that the median sequence length of human proteins is 325 amino acids (Fig. 1a). The largest human protein is Titin with 34,350 amino acids.

Structure forms the basis of protein function: The three- dimensional structure/conformation of the polypeptide chain determines the dynamics and, then more or less directly the function of an individual protein. Proteins excluding intrinsic disordered proteins (IDPs) typically have at least one natively folded conformation. Structural biology techniques, principally X-Ray crystallography, NMR spectroscopy and recently Cryogenic Electron Microscopy (cryo-EM) have allowed us to obtain medium to high resolution protein structures with increased accuracy and efficiency over the years. Such structures are deposited in the Protein Databank, the PDB and in 2019 alone, 10,585 protein structures were released. As of July 2020, there are 167,780 structures in the PDB. Despite this large number of PDB items, the real number of canonical/non-redundant human proteins with known structures is unclear, as many PDB entries correspond to the same protein solved by different groups, single point mutants or the same protein bound to different ligands, ranging from small molecule inhibitors to protein or other macromolecular binding partners. As mentioned above, there are 20,367 reviewed entries of full length human proteins in the Uniprot database. By reading these proteins one by one into a python script, we found 6,747 out of the 20,367 distinct human proteins have at least one PDB item for at least a segment/domain of the entire protein. Thus, at least $2 / 3 \mathrm{rds}$ of the structures of the human proteome remain to be determined. The distribution of available PDB items amongst these protein species are plotted in Fig. 1b. Amongst these proteins, 1,978, 1,051 and 775 proteins, have only one, two or three pdb entries respectively (together, then $56 \%$ of the 6,747 proteins have only 1-3 entries). However, at the other extreme, the 200 proteins with the most entries $(3 \%$ of 6,747$)$ have 21,645 cumulative PDB entries, remarkably counting at least $40 \%$ of total human PDB items (totally 46, 581) in the Uniprot database. Thus, the top human 200 proteins have gathered an unusually high proportion of attention compared to the rest.

The human proteins with the highest number of pdb entries were identified as follows: We downloaded the data of individual human protein species from the Uniprot web server. Only reviewed items (the set of 20,367 canonical proteins) were downloaded. From the downloaded file, we extracted the PDB items of each protein species and sorted them by adding the total number of available PDB items for each protein species. It should be noted that this number includes structures of fragments or domains because the determination of full length structures is still rare or not yet possible for certain types of proteins, such as the great majority of single membrane crossing receptors. 
In case of a human protein in a protein-protein complex, the human segment bound may be very small, e.g. a peptide and the partner protein may not be human (e.g. in case of interactions with microorganisms). We also considered isoforms in the analysis, but assumed that the latin name for human "homo sapiens" was mentioned in the Uniprot entries for all human proteins. The top 200 human proteins counting the number of the PDB items is given in Table 1. Separately, we also list the 100 transmembrane proteins with the most entries (Table 2). Since 28 membrane proteins already appear in the first part of Table 1, so in total only 272 unique proteins are listed. Overall, the high frequency appearance of the proteins in the $\mathrm{pdb}$ arises from the biological importance that they have in cellular processes, in human diseases but some also to an increasingly lesser extent from their use as model systems for our understanding of protein structure and function. Below we comment on some of the most highly representative structures/families which have emerged, also making a note of the early history of protein structural biology.

It should be noted that the method we used to rank the top-hit proteins is completely different from the approach used in the report by Dolgin in 2017, where the top 10 genes in the human genome are identified by counting the frequency of appearance of a gene in the PubMed database. ${ }^{3}$ By contrast, we count the absolute number of available PDB entries for each protein in the Uniprot websever. However, the two methods corroborate each other in part--some of top genes identified in the study of Dolgin, such as Cellular tumor antigen p53, Tumor necrosis factor, Epidermal growth receptor and Estrogen Receptor also appear in our lists.
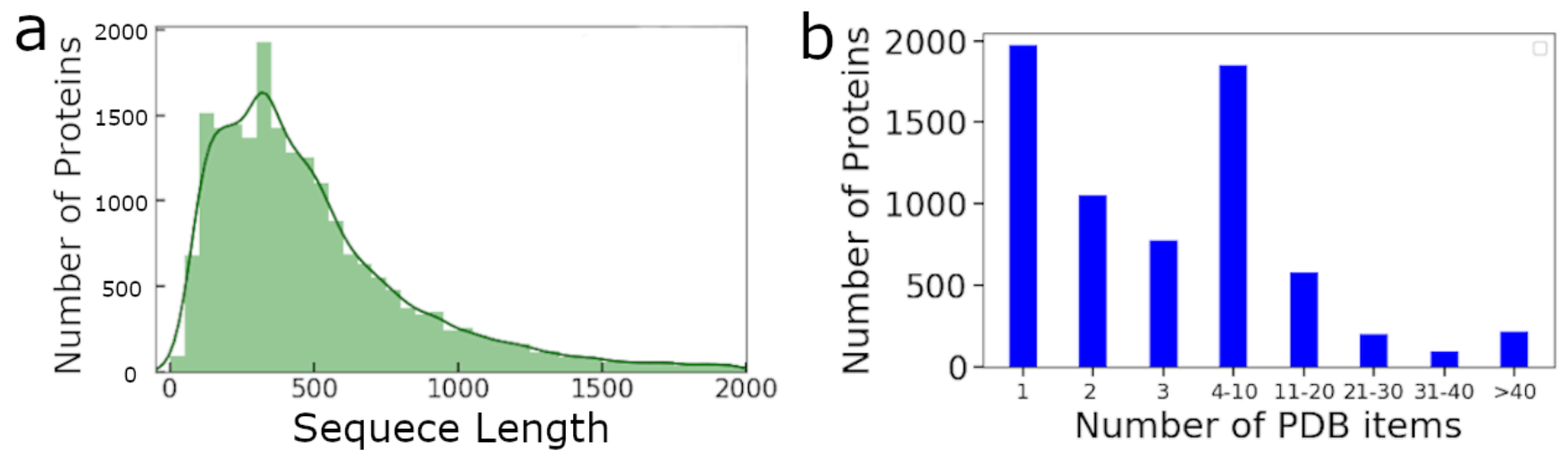

Figure 1: Protein sequence and structure statistics. (a) Distribution of sequence lengths for 20,367 human proteins. (b) PDB statistics as of July 2020. Number of proteins with 1, 2, 3 and more PDB items.

Top 10 Aqueous And Membrane Proteins Identified: By far the most structures solved are for Beta-2microglobulin, Carbonic anhydrase 2 and Cyclin-dependent kinase 2 as the first, second, third place of the most deposited structures in the PDB, with 770, 766 and 410 entries respectively. Prothrombin; Beta-secretase 1; DNA polymerase beta; HLA class I histocompatibility antigen, A alpha Chain; Transthyretin; Bromodomain-containing protein 4; DNA cross-link repair 1A protein ranks 4-10.

The top 10 for membrane proteins (with transmembrane regions) are listed below: Beta-secretase 1; HLA class I histocompatibility antigen, A alpha chain; Estrogen receptor; HLA class I histocompatibility antigen, B alpha chain; Epidermal growth factor receptor; Histo-blood group ABO system transferase; Amyloid-beta precursor protein; Dipeptidyl peptidase 4; HLA class II histocompatibility antigen, DR alpha chain; Hepatocyte growth factor receptor.

Protein Classification: Of all the 20,000 canonical human proteins, noticeable protein groupings include 1,653 metabolic enzymes; 1,089 non-metabolic enzyme such as kinase and GTPases; 1,600 transcription factors; at least 1,555 transporters and channels; and 831 GPCRs. ${ }^{4-6}$ By contrast, among the 272 top-hit proteins listed in the tables, there are 73 metabolic enzymes, 5 GTP-/ATPases, 44 kinases, 16 transcription factors, 5 ion channels and 4 Gprotein-coupled receptors (GPCRs). Moreover, there are 11 human leukocyte antigens, 5 histone proteins, 5 bromodomain (BRD) containing proteins, 4 Hormone and Growth factors, 10 cell adhesion molecules, and 6 cystic fibrosis family proteins. The other 84 of 272 proteins are not classified into major protein families, but all of them have important biological functions. Here we comment on several of the families.

Kinase as One of The Best Studied Protein Family: The high frequency of appearance of kinases (44 of 272) is remarkable in contrast to its low fraction amongst the 20,000 canonical human proteins (518 of 20,000). Protein kinases are thought to modify up to $30 \%$ of all human proteins and many of them such as Raf kinase, Akt kinase, Ephrin type-A receptor 2 and Epidermal growth factor receptor (EGFR) have a crucial role in disease development, 
especially in cancer. ${ }^{7}$ Clinically, more than 250 kinase inhibitors are undergoing clinical trials and 37 are already approved as therapeutics. ${ }^{8}$ Due to this biomedical significance, kinases are one of the most well studied families of human proteins.

Membrane Protein Structures: Membrane proteins represent 20-30\% of human proteins. In many earlier reports, it was noted that the membrane proteins are largely underrepresented (only $\sim 2 \%$ of all PDB items) in structure determination by comparison to their number in genomes. This number is inaccurate today, however, especially for human proteins. If we count all peripheral-, transmembrane and integral membrane proteins, 2,237 distinct membrane proteins have at least one structure, corresponding to $33.2 \%$ of all available human protein structures. By counting single-pass and multi-pass transmembrane proteins only, 1,132 of 6,747 (16.8\%) proteins with available structures are membrane proteins. In both cases, this is close to the proportional number of membrane proteins in the human genome. However, it is true that integral membrane proteins such as transporters, ion channels and GPCRs, are still not presented well in the top 272 proteins with most of pdb items. This is despite the fact that GPCRs for example account for approx. $30 \%$ of all drug targets. Several proteins of intense research interest are in the top-100 table for membrane proteins and others are catching up. Until recently integral membrane proteins typically had much fewer pdb items than soluble proteins. This is at least partially due to difficulties in protein expression and purification. Transmembrane proteins such as Receptor Tyrosine Kinases (such as EGF receptors and Eph receptors) and Cell Adhesion proteins (such as Integrin) are prominently represented in the lists. However, these proteins have the majority of domains exposed in solvent, and it is these domains whose structure has been mostly determined, excluding the single membrane crossing segment; there are only a few structures available for the membrane crossing regions typically from NMR (about 27 as of 2017). ${ }^{9}$ Due to the technical challenges with sample preparation and likely the dynamic nature of the structures, the determination of full length TM protein structures remains a frontier of structural biology, with increasing success reported by use of NMR, molecular modeling and cryo-EM incl. cryo-electron tomography (cryo-ET). 
Table 1: Human proteins with the most PDB entries. The top 200 ranked proteins and are listed alphabetically (the top 10 of all proteins in blue).

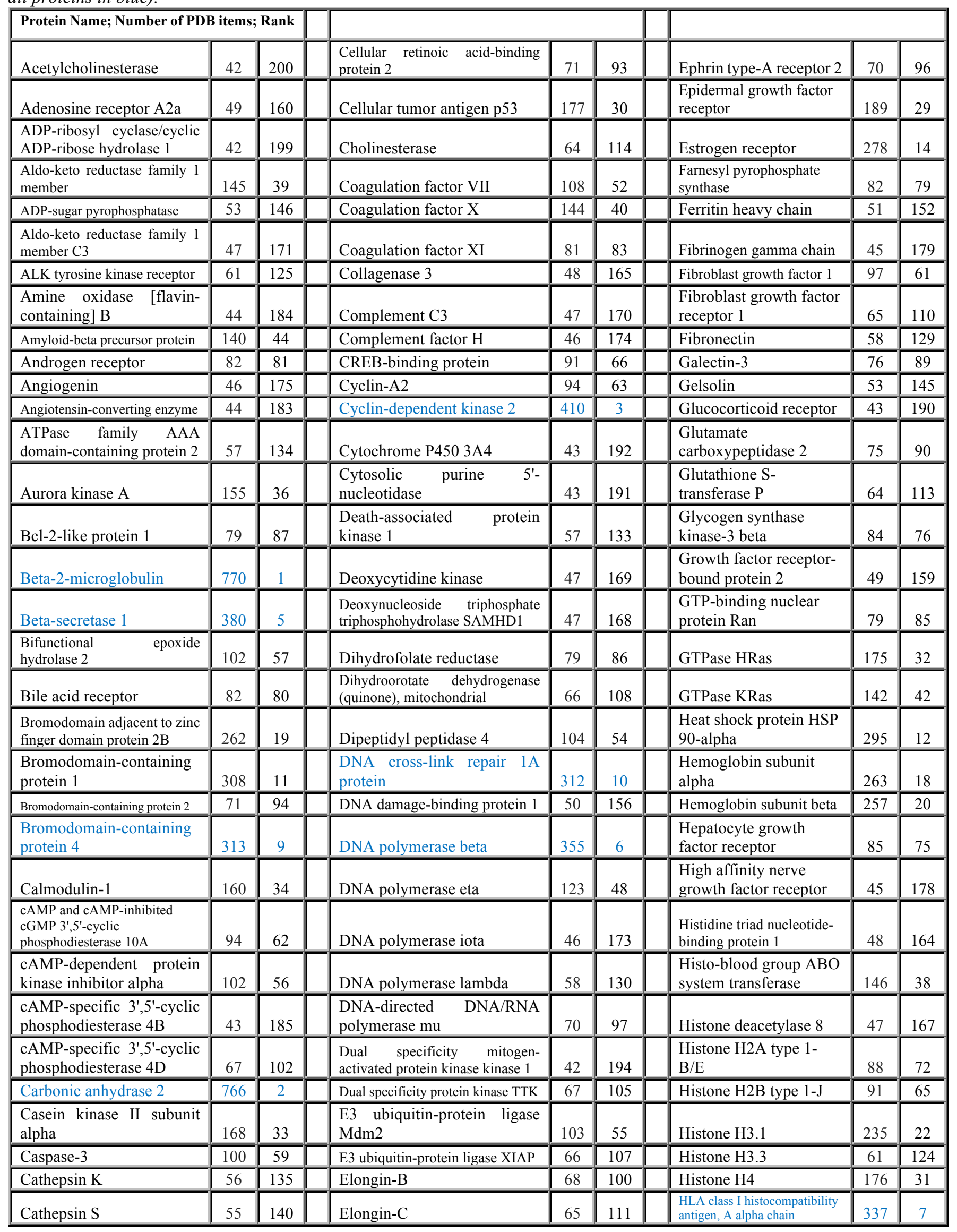




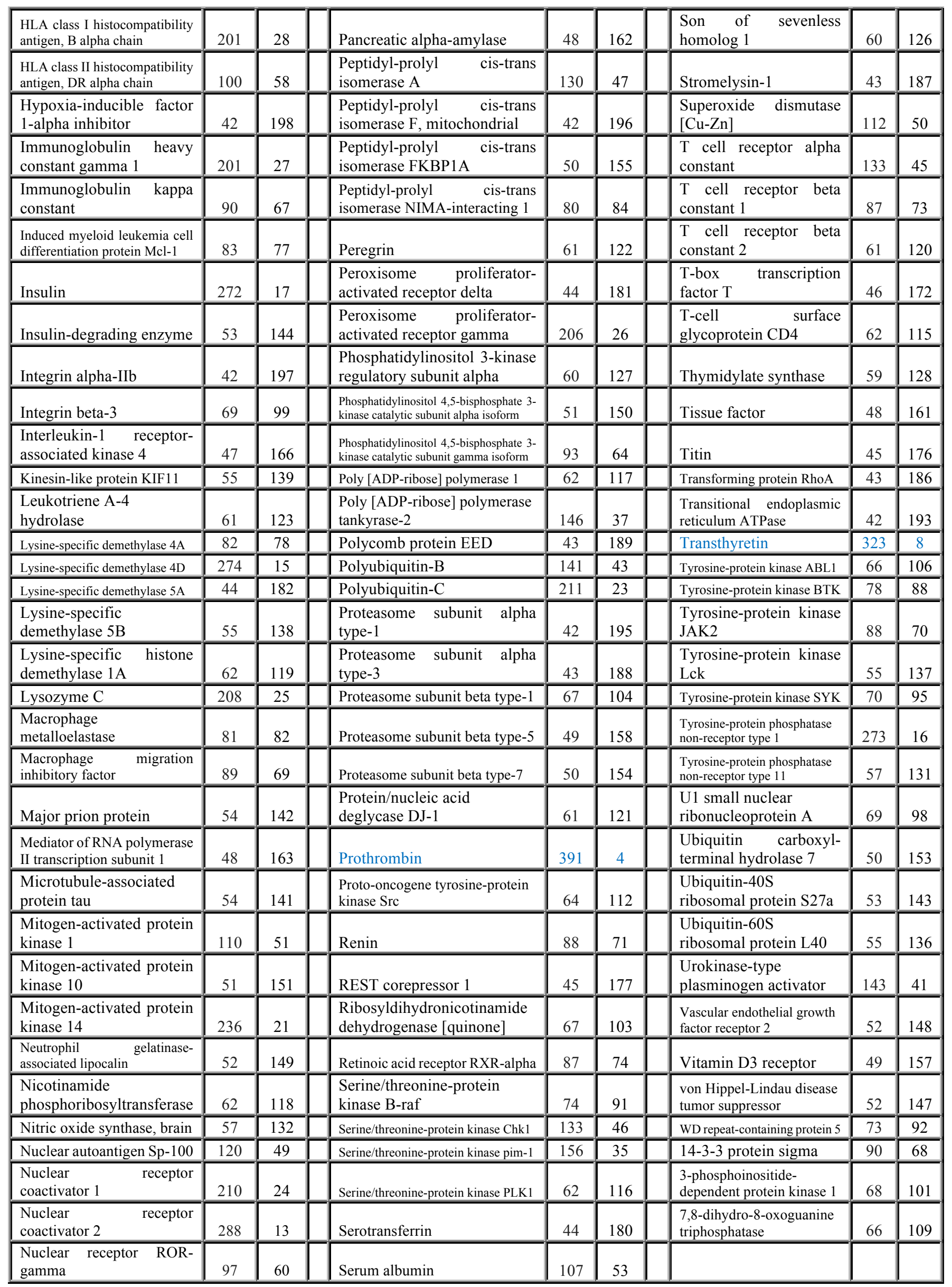


Table 2: Top 100 membrane proteins with most of the pdb items. The top 28 proteins also appear in Table 1.

\begin{tabular}{|c|c|c|c|c|c|c|c|c|}
\hline Activin receptor type-1 & 16 & 90 & $\begin{array}{l}\text { Disintegrin and metalloproteinase } \\
\text { domain-containing protein } 17\end{array}$ & 23 & 58 & Integrin alpha-V & 21 & 78 \\
\hline Adenosine receptor A2a & 49 & 21 & Ephrin type-A receptor 2 & 70 & 14 & Integrin alpha-2 & 17 & 67 \\
\hline $\begin{array}{l}\text { Advanced glycosylation end } \\
\text { product-specific receptor }\end{array}$ & 22 & 60 & Ephrin type-A receptor 3 & 27 & 54 & Integrin beta- 3 & 69 & 15 \\
\hline ALK tyrosine kinase receptor & 61 & 19 & Ephrin type-A receptor 4 & 15 & 55 & Leukotriene $\mathrm{C} 4$ synthase & 16 & 84 \\
\hline $\begin{array}{l}\text { Amine oxidase [flavin- } \\
\text { containing] B }\end{array}$ & 44 & 25 & Ephrin type-B receptor 4 & 23 & 57 & $\begin{array}{l}\text { Low affinity immunoglobulin } \\
\text { epsilon Fc receptor }\end{array}$ & 23 & 56 \\
\hline Amyloid-beta precursor protein & 140 & 7 & Epidermal growth factor receptor & 189 & 5 & Low-density lipoprotein receptor & 33 & 35 \\
\hline $\begin{array}{l}\text { ADP-ribosyl cyclase/cyclic } \\
\text { ADP-ribose hydrolase } 1\end{array}$ & 42 & 28 & $\begin{array}{l}\text { Epithelial discoidin domain- } \\
\text { containing receptor } 1\end{array}$ & 20 & 65 & $\begin{array}{l}\text { Low-density lipoprotein } \\
\text { receptor-related protein } 6\end{array}$ & 16 & 83 \\
\hline Angiopoietin-1 receptor & 15 & 91 & Erythropoietin receptor & 18 & 72 & $\begin{array}{l}\text { Macrophage colony-stimulating } \\
\text { factor } 1 \text { receptor }\end{array}$ & 19 & 69 \\
\hline $\begin{array}{l}\text { Angiotensin-converting } \\
\text { enzyme }\end{array}$ & 44 & 24 & Estrogen receptor & 278 & 3 & $\begin{array}{l}\text { Major histocompatibility complex } \\
\text { class I-related gene protein }\end{array}$ & 31 & 38 \\
\hline $\begin{array}{l}\text { Angiotensin-converting } \\
\text { enzyme } 2\end{array}$ & 16 & 89 & Fibroblast growth factor receptor 1 & 65 & 17 & $\begin{array}{l}\text { Mast/stem cell growth factor } \\
\text { receptor Kit }\end{array}$ & 23 & 55 \\
\hline $\begin{array}{l}\text { Antigen-presenting } \\
\text { glycoprotein CD1d }\end{array}$ & 15 & 92 & Fibroblast growth factor receptor 2 & 41 & 29 & $\begin{array}{l}\text { Melanoma antigen recognized by } \\
\text { T-cells } 1\end{array}$ & 22 & 59 \\
\hline Apoptosis regulator BAX & 24 & 52 & Fibroblast growth factor receptor 4 & 25 & 45 & $\begin{array}{lll}\text { Neurogenic locus } & \text { notch } \\
\text { homolog protein } 1 & \\
\end{array}$ & 24 & 49 \\
\hline Apoptosis regulator $\mathrm{Bcl}-2$ & 26 & 42 & Furin & 21 & 63 & Neuropilin-1 & 17 & 77 \\
\hline $\begin{array}{l}\text { Bcl-2 homologous } \\
\text { antagonist/killer }\end{array}$ & 25 & 47 & $\begin{array}{l}\text { Glucagon-like peptide } 1 \\
\text { receptor }\end{array}$ & 15 & 96 & $\begin{array}{l}\text { Platelet glycoprotein Ib } \\
\text { alpha chain }\end{array}$ & 19 & 68 \\
\hline Bcl-2-like protein 1 & 79 & 12 & $\begin{array}{l}\text { Glutamate receptor ionotropic, } \\
\text { NMDA } 1\end{array}$ & 17 & 79 & $\begin{array}{l}\text { Potassium channel } \\
\text { subfamily K member } 9\end{array}$ & 16 & 82 \\
\hline $\begin{array}{l}\text { Beta-1, } \\
\text { galactosyltransferase 1 }\end{array}$ & 19 & 71 & $\begin{array}{l}\text { Glutamate receptor ionotropic, } \\
\text { NMDA } 2 \mathrm{~A}\end{array}$ & 15 & 99 & $\begin{array}{l}\text { Programmed cell death } 1 \\
\text { ligand } 1\end{array}$ & 31 & 37 \\
\hline Beta-2 adrenergic receptor & 25 & 46 & Glutamate carboxypeptidase 2 & 75 & 13 & Prostaglandin E synthase & 16 & 81 \\
\hline Beta-secretase 1 & 380 & 1 & Hepatocyte growth factor receptor & 85 & 10 & $\begin{array}{l}\text { Proto-oncogene tyrosine-protein } \\
\text { kinase receptor Ret }\end{array}$ & 25 & 43 \\
\hline $\begin{array}{l}\text { Butyrophilin subfamily } \\
3 \text { member A1 }\end{array}$ & 15 & 93 & $\begin{array}{l}\text { High affinity nerve growth factor } \\
\text { receptor }\end{array}$ & 45 & 23 & $\begin{array}{l}\text { Receptor tyrosine-protein kinase } \\
\text { erbB-2 }\end{array}$ & 34 & 34 \\
\hline $\begin{array}{l}\text { C-C chemokine receptor } \\
\text { type } 5\end{array}$ & 18 & 76 & $\begin{array}{l}\text { Histo-blood group } \mathrm{ABO} \text { system } \\
\text { transferase }\end{array}$ & 146 & 6 & $\begin{array}{l}\text { Receptor-type tyrosine-protein } \\
\text { phosphatase gamma }\end{array}$ & 19 & 67 \\
\hline $\begin{array}{l}\text { C-type lectin domain } \\
\text { family } 4 \text { member } \mathrm{K}\end{array}$ & 20 & 66 & $\begin{array}{l}\text { HLA class I histocompatibility } \\
\text { antigen, A alpha chain }\end{array}$ & 337 & 2 & Squalene synthase & 26 & 41 \\
\hline Cadherin-1 & 18 & 75 & $\begin{array}{l}\text { HLA class I histocompatibility } \\
\text { antigen, B alpha chain }\end{array}$ & 201 & 4 & $\begin{array}{l}\text { Stimulator of interferon } \\
\text { genes protein }\end{array}$ & 30 & 39 \\
\hline Carbonic anhydrase 12 & 18 & 74 & $\begin{array}{l}\text { HLA class II histocompatibility } \\
\text { antigen, DR alpha chain }\end{array}$ & 100 & 9 & $\begin{array}{l}\text { Suppressor of tumorigenicity } \\
14 \text { protein }\end{array}$ & 23 & 54 \\
\hline $\begin{array}{l}\text { Cation-independent } \\
\text { mannose-6-phosphate receptor }\end{array}$ & 18 & 73 & $\begin{array}{l}\text { HLA class II histocompatibility } \\
\text { antigen gamma chain }\end{array}$ & 15 & 97 & Synaptotagmin-1 & 15 & 98 \\
\hline CD81 antigen & 15 & 94 & $\begin{array}{l}\text { HLA class I histocompatibility } \\
\text { antigen, alpha chain E }\end{array}$ & 16 & 87 & $\begin{array}{l}\text { T-cell surface } \\
\text { glycoprotein CD1b }\end{array}$ & 16 & 80 \\
\hline $\begin{array}{l}\text { Chloride intracellular } \\
\text { channel protein } 1\end{array}$ & 15 & 95 & $\begin{array}{l}\text { HLA class II histocompatibility } \\
\text { antigen, DQ alpha } 1 \text { chain }\end{array}$ & 16 & 86 & $\begin{array}{l}\text { T-cell surface } \\
\text { glycoprotein CD4 }\end{array}$ & 62 & 18 \\
\hline $\begin{array}{l}\text { Complement decay- } \\
\text { accelerating factor }\end{array}$ & 24 & 51 & $\begin{array}{l}\text { HLA class II histocompatibility } \\
\text { antigen, DRB } 1 \text { beta chain }\end{array}$ & 19 & 70 & Tissue factor & 48 & 22 \\
\hline $\begin{array}{l}\text { Copper-transporting } \\
\text { ATPase } 1\end{array}$ & 21 & 64 & $\begin{array}{l}\text { Induced myeloid leukemia cell } \\
\text { differentiation protein Mcl-1 }\end{array}$ & 83 & 11 & TGF-beta receptor type- 1 & 37 & 32 \\
\hline $\begin{array}{l}\text { Corticosteroid 11-beta- } \\
\text { dehydrogenase isozyme } 1\end{array}$ & 40 & 30 & Insulin receptor & 35 & 33 & Toll-like receptor 8 & 24 & 48 \\
\hline $\begin{array}{ll}\text { Coxsackievirus } & \text { and } \\
\text { adenovirus receptor } & \end{array}$ & 16 & 88 & $\begin{array}{l}\text { Insulin-like growth factor } 1 \\
\text { receptor }\end{array}$ & 25 & 44 & Tumor necrosis factor & 23 & 53 \\
\hline $\begin{array}{l}\text { Cystic fibrosis transmembrane } \\
\text { conductance regulator }\end{array}$ & 32 & 36 & Integrin alpha-IIb & 42 & 27 & $\begin{array}{l}\text { Vascular endothelial growth } \\
\text { factor receptor } 2\end{array}$ & 52 & 20 \\
\hline Cytochrome P450 3A4 & 43 & 26 & Integrin alpha-2 & 39 & 31 & $\begin{array}{l}\text { 3-hydroxy-3-methylglutaryl- } \\
\text { coenzyme A reductase }\end{array}$ & 22 & 61 \\
\hline $\begin{array}{l}\text { Dihydroorotate dehydrogenase } \\
\text { (quinone), mitochondrial }\end{array}$ & 66 & 16 & Integrin alpha-L & 16 & 85 & & & \\
\hline Dipeptidyl peptidase 4 & 104 & 8 & Integrin alpha-M & 24 & 50 & & & \\
\hline
\end{tabular}


Historical Implication and Model Proteins for Protein Science: Several of the proteins listed in the tables have historical contexts and/or have become model proteins for structural biology and protein biophysics research. However, it should be noted that some of well-known proteins (from the other organisms) in protein history do not appear in the tables, as here we have adhered to human proteins. Due to the challenge of crystallization especially of eukaryotic proteins, traditionally crystallographers have tried their luck with a wide range species approach, especially in the days when proteins had to be purified from the organism itself. With the advent of recombinant protein expression, the focus shifted to prokaryotic homologues of human proteins and then with the mandate of several structural genomics efforts to work on human proteins. The number of human proteins in the PDB received a significant boost. As an reference, if counting all the species, the number of pdb items for proteins with the largest representation are the following (12 are listed): (Lysozyme C - chicken, 834 items); (Beta-2-microglobulin - human, 770); (Carbonic anhydrase 2 - human, 766); (Endolysin - bacteriophage, 702); (Endothiapepsin - endothia parasitica, 532); (Cationic trypsin - bovine, 487); (Cyclin-dependent kinase 2 -human, 410); (Prothrombin - human, 391); (Beta-secretase 1 - human, 380); (DNA polymerase beta -human, 355); (HLA class I histocompatibility antigen, A alpha chain -human, 337); (Green fluorescent protein - jellyfish, 332). Seven of these twelve proteins have human source.

The studies of Hemoglobin, Insulin, G-proteins, Na-K-ATPase, Prion, Cyclin dependent kinase, Ion channels, Ubiquitin, GPCRs and PD-L1 have been recognized with the Nobel prize. For example, Myoglobin and Hemoglobin were the earliest proteins to have their 3D structure revealed by $x$-Ray crystallography. Hemoglobin was also the first well known allosteric protein complex identified in the 1960s and a key advance in our understanding of cooperativity. ${ }^{10}$ Myoglobin and Cytochrome are early known examples of structure-based allostery for an individual protein. In biophysical research, Ubiquitin, individually or as a multi-protein chain, are is a model protein for studying protein conformational as well as configurational ensembles, protein dynamics and protein association/recognition. ${ }^{11}$ Calmodulin and Lysosome were widely used in the earlier NMR characterization of protein dynamics and conformational entropy. ${ }^{12} \mathrm{H}$ - and KRas are recently used as model proteins for investigating the multi-orientational nature of protein configurations at the cells plasma membrane. ${ }^{13}$ Recently, p53 and Estrogen receptor have also been studied with respect to their likely changes over the course of evolution. ${ }^{14}$

Relevance to Human Disease: Many of the 272 proteins are important for their involvement in human diseases and remain a current focus of research. For example, the (Low-density lipoprotein receptor) LDL receptor is vital for the regulation of the concentration of human lipoprotein which tracks human fat content. Proteins such as p53, Ras GPTases, Estrogen receptor and 14-3-3- proteins are crucial proteins either in cancer development or cancer metastasis. ${ }^{15}$ Fibroblast growth factors and Neuropilin-1 are vital factors for human cell development. Cytokines and Cell adhesion molecules such as human leukocyte antigen, Tumor necrosis factor and T-cell surface glycoprotein CD4, are important for immunity. Amyloid-beta precursor proteins, Microtubule-associated protein tau and the prion protein are crucial for development of neuronal diseases. ${ }^{16}$ Angiotensin-converting enzyme 2 (ACE2) and recently Neuropilin-1 were identified as entry receptor for coronavirus SARS-COV-2. ${ }^{17,18}$

In summary, we considered the number of human proteins with fully or partially available medium to high resolution structures among the 20,000 or so canonical human proteins. From this set, we identified 272 protein structures with the most number of items in the PDB. These proteins are also the ones which have been a focus of intense studies, either because of their history as model systems, and more recently as proteins with high biomedical relevance. Many of these proteins have influenced our understanding of protein structural and functions biology as well as biophysics. The information we provided here should be helpful to researchers who are new to protein science, as in a sea of proteins, the top-studied proteins may serve as "Lighthouses" for future investigations. However, our analysis may also interest structural biologists, as a "Stamp in Time", showing how far Protein Science has moved and "the Waters which may lie ahead".

\section{Acknowledgements}

This work is supported by a NIH R01 grant from the National Eye Institute R01EY029169 and previous grants from NIGMS (R01GM073071 and R01GM092851) to the Buck lab.

\section{Author Contribution}

Z.L. analyzed the ranking of protein based on available PDB items. Z.L. and M.B. wrote the manuscript.

\section{Competing Interests}

The authors declare no competing interests. 


\section{Reference}

1. Kim Min-Sik, et al “A draft map of the human proteome.” Nature. 509, no 7502 (2014): 575-581. doi: 10.1038/nature13302. 2. Ponomarenko, Elena A., Ekaterina V. Poverennaya, Ekaterina V. Ilgisonis, Mikhail A. Pyatnitskiy, Arthur T. Kopylov, Victor G. Zgoda, Andrey V. Lisitsa, and Alexander I. Archakov. "The Size of the Human Proteome: The Width and Depth." International Journal of Analytical Chemistry 2016 (2016): 1-6. doi:10.1155/2016/7436849.

3. Dolgin, Elie. "The Most Popular Genes in the Human Genome." Nature 551, no. 7681 (2017): 427-31. doi:10.1038/d41586017-07291-9.

4. Rubin, G. M. "Comparative Genomics of the Eukaryotes." Science 287, no. 5461 (2000): $2204-215$. doi:10.1126/science.287.5461.2204.

5. Romero, Pedro, Jonathan Wagg, Michelle L. Green, Dale Kaiser, Markus Krummenacker, and Peter D Karp. "Computational prediction of human metabolic pathways from the complete human genome." Genome Biology 6, no. 1 (2005): R2. doi: 10.1186/gb-2004-6-1-r2.

6. Lambert, Samuel A., Arttu Jolma, Laura F. Campitelli, Pratyush K. Das, Yimeng Yin, Mihai Albu, Xiaoting Chen, Jussi Taipale, Timothy R. Hughes, and Matthew T. Weirauch. "The Human Transcription Factors." Cell 175, no. 2 (2018): 598-99. doi:10.1016/j.cell.2018.09.045.

7. Miao, Hui, Da-Qiang Li, Amitava Mukherjee, Hong Guo, Aaron Petty, Jennifer Cutter, James P. Basilion, John Sedor, Jiong Wu, David Danielpour, Andrew E. Sloan, Mark L. Cohen, and Bingcheng Wang. "EphA2 Mediates Ligand-Dependent Inhibition and Ligand-Independent Promotion of Cell Migration and Invasion via a Reciprocal Regulatory Loop with Akt." Cancer Cell 16, no. 1 (2009): 9-20. doi:10.1016/j.ccr.2009.04.009.

8. Wu, Peng, Thomas E. Nielsen, and Mads H. Clausen. "FDA-approved Small-molecule Kinase Inhibitors." Trends in Pharmacological Sciences 36, no. 7 (2015): 422-39. doi:10.1016/j.tips.2015.04.005.

9. Bocharov, Eduard V., Dmitry M. Lesovoy, Konstantin V. Pavlov, Yulia E. Pustovalova, Olga V. Bocharova, and Alexander S. Arseniev. "Alternative Packing of EGFR Transmembrane Domain Suggests That Protein-lipid Interactions Underlie Signal Conduction across Membrane." Biochimica Et Biophysica Acta (BBA) - Biomembranes 1858, no. 6 (2016): $1254-261$. doi:10.1016/j.bbamem.2016.02.023.

10. Monod, Jacques, Jean-Pierre Changeux, and François Jacob. "Allosteric Proteins and Cellular Control Systems." Journal of Molecular Biology 6, no. 4 (1963): 306-29. doi:10.1016/s0022-2836(63)80091-1.

11. Lange, O. F., N.-A. Lakomek, C. Fares, G. F. Schroder, K. F. A. Walter, S. Becker, J. Meiler, H. Grubmuller, C. Griesinger, and B. L. De Groot. "Recognition Dynamics Up to Microseconds Revealed from an RDC-Derived Ubiquitin Ensemble in Solution." Science 320, no. 5882 (2008): 1471-475. doi:10.1126/science.1157092.

12. Frederick, Kendra King, Michael S. Marlow, Kathleen G. Valentine, and A. Joshua Wand. "Conformational Entropy in Molecular Recognition by Proteins." Nature 448, no. 7151 (2007): 325-29. doi:10.1038/nature05959.

13. Prakash, Priyanka, Yong Zhou, Hong Liang, John F. Hancock, and Alemayehu A. Gorfe. "Oncogenic K-Ras Binds to an Anionic Membrane in Two Distinct Orientations: A Molecular Dynamics Analysis." Biophysical Journal 110, no. 5 (2016): 1125-138. doi:10.1016/j.bpj.2016.01.019.

14. Harms, M. J., G. N. Eick, D. Goswami, J. K. Colucci, P. R. Griffin, E. A. Ortlund, and J. W. Thornton. "Biophysical Mechanisms for Large-effect Mutations in the Evolution of Steroid Hormone Receptors." Proceedings of the National Academy of Sciences 110, no. 28 (2013): 11475-1480. doi:10.1073/pnas.1303930110.

15. Prior, I. A., P. D. Lewis, and C. Mattos. "A Comprehensive Survey of Ras Mutations in Cancer." Cancer Research 72 , no. 10 (2012): 2457-467. doi:10.1158/0008-5472.can-11-2612.

16. O'brien, Richard J., and Philip C. Wong. "Amyloid Precursor Protein Processing and Alzheimer's Disease." Annual Review of Neuroscience 34, no. 1 (2011): 185-204. doi:10.1146/annurev-neuro-061010-113613

17. Shang, Jian, Gang Ye, Ke Shi, Yushun Wan, Chuming Luo, Hideki Aihara, Qibin Geng, Ashley Auerbach, and Fang Li. "Structural Basis of Receptor Recognition by SARS-CoV-2." Nature 581, no. 7807 (2020): 221-24. doi:10.1038/s41586-0202179-y.

18. Daly, James L., Boris Simonetti, Carlos Antón-Plágaro, Maia Kavanagh Williamson, Deborah K. Shoemark, Lorena SimónGracia, Katja Klein, Michael Bauer, Reka Hollandi, Urs F. Greber, Peter Horvath, Richard B. Sessions, Ari Helenius, Julian A. Hiscox, Tambet Teesalu, David A. Matthews, Andrew D. Davidson, Peter J. Cullen, and Yohei Yamauchi. "Neuropilin-1 Is a Host Factor for SARS-CoV-2 Infection." 2020. BioRxiv doi:10.1101/2020.06.05.134114. 